\title{
Protein Kinase Receptor Binding
}

National Cancer Institute

\section{Source}

National Cancer Institute. Protein Kinase Receptor Binding. NCI Thesaurus. Code C40534.

A process that involves the binding of a cognate ligand to a transmembrane receptor.

These interactions are involved in signaling pathways that influence cellular division, cellular differentiation and morphogenesis. 